\title{
加エフィーチャを用いた事例ベース推論による 作業設計支援システムの開発に関する研究*
}

\author{
淺野哲 也** 塚 本 涼*** 中 本圭 ${ }^{* \dagger}$
}

Study on Development of an Operation Planning System Based on Case-Based Reasoning Using Machining Features

Tetsuya ASANO, Ryo TSUKAMOTO and Keiichi NAKAMOTO

High-speed and high-precision machine tools developed recently have contributed to shorten machining time in parts machining. However, it consumes long time to determine operation parameters such as machining area, machining method, cutting tool and cutting conditions, and they deeply depend on operators' knowledge and experience. Thus, the preparation time before parts machining remains as a critical issue to be solved to achieve high-mix low-volume production. Therefore, in order to improve the efficiency of process planning, this study proposes an operation planning system to derive operation parameters based on case-based reasoning using recognized machining features. By using information of machining features, it becomes possible to widely deal with operation parameters such as not only cutting tool and cutting conditions, but also tool approaching and retracting patterns that are required to be input in CAM system. Additionally, since machining cases are added to a case database sequentially, the rules for case retrieval are automatically adjusted to utilize the past machining cases effectively in this system. From the result of a case study, it is confirmed that the developed system has a possibility to derive proper operation parameters in parts machining.

Key words: operation planning system, case-based reasoning, machining feature, CAM system, parts machining

\section{1. 緒論}

製造業の生産形態は, 大量生産から多品種少量生産へと移行 し, 近年では多様な製品を迅速かつ効辩的に生産する必要性が 高まっている. これに伴い, 製品形状や製品製造情報から加工工 程を計画する工程設計, 詳細な実施内容を計画する作業設計な ど, 加工工程を開始するまでの準備時間を含めた効率化が望ま

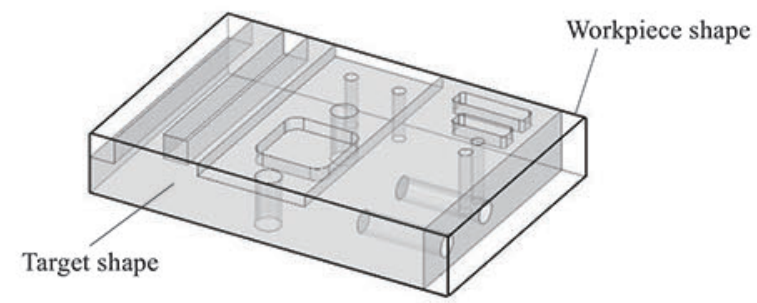

(a) Workpiece and target shapes

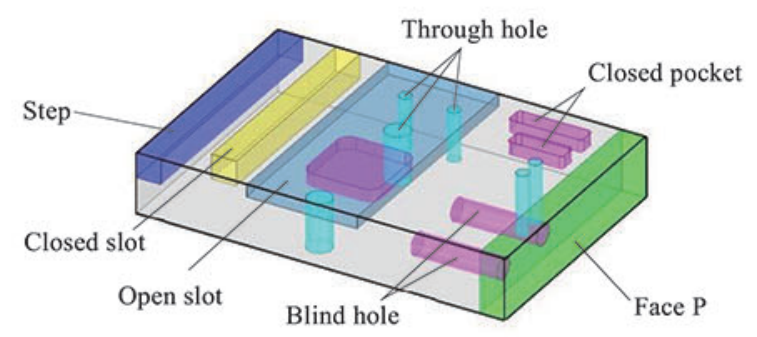

(b) Recognized machining features

Fig. 1 Machining features recognition in the author's previous study')

* 原稿受付 令和 2 年 12 月 21 日 揭載決定 令和 3 年 2 月 26 日

**アイコクアルファ株式会社（愛知県稲沢市祖父江町森上 本郷 11-4-1)

***東京農工大学大学院（東京都小金井市中町 2-24-16)

†正会员 東京農工大学大学院
れている. 機械加工においては, 数值制御工作機械を運転するた めの NC プログラムを生成する CAM ソフトウェアが導入され, 加工工程自体の効率化は進んでいる. しかしながら, 加工箅所, 加工方法, 使用工具や切削条件などの CAM ソフトウェアで必 要な情報は, 作業者の知識や経験に基づいて決定されることが 多く標準化が進んでいない. さらに, 加工現場特有のノウハウに も依存するため, 加工経験の浅い作業者にとっては大きな負担 となる. そこで, 加工工程の準備時間を短縮するために, 工程設 計や作業設計を支援するシステムの開発が求められている.

工程設計支援システムの開発に向けて, 目標形状や除去領域 から加工フィーチャと呼ばれる特徴形状を認或する方法が盛ん に研究されており 1) 4), 著者らも目標形状と接する創成面の数 や種類などにより分類した新たな加エフィーチャを提案してい る ${ }^{5)}$.この加工フィーチャはワーク形状と目標形状の差である除 去領域を複数通りに分割した加工プリミティブごとに, 加工順 序を決定しながら認識され, 図 1 に部品加工を想定したケース スタディにおいて加工フィーチャを認識した例を示すの. しかし, その後の作業設計では, 認識された各加工フィーチャの加工作 業に関わる情報 (以下, 作業情報) を独自に考案したルールに基 ついて決定しており, 妥当性の検証が不十分であった.

一方, 作業設計の支援に向けた研究も数多く存在し 7) 9), 本研 究と同様に, 認識された加エフィーチャと類似した加エフィー チャの加工作業の事例 (以下, 加工事例) を利用して, NCプロ

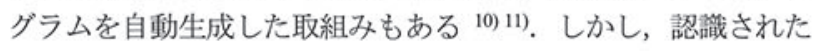
加工フィーチャに応じた工具経路, 加工領域や切削条件の修正 は作業者に委ねられており, 更なる自動化が求められる. また, 本研究でも採用した事例ベース推論により工具回転速度, 切削 速度, 送り速度や切込み量などの切削条件を推定した取組みも あるが ${ }^{12)}, \mathrm{NC}$ プログラムの生成には切削条件のみでは不十分で あり，加工方法や使用工具などの作業情報の推定が欠かせない. 


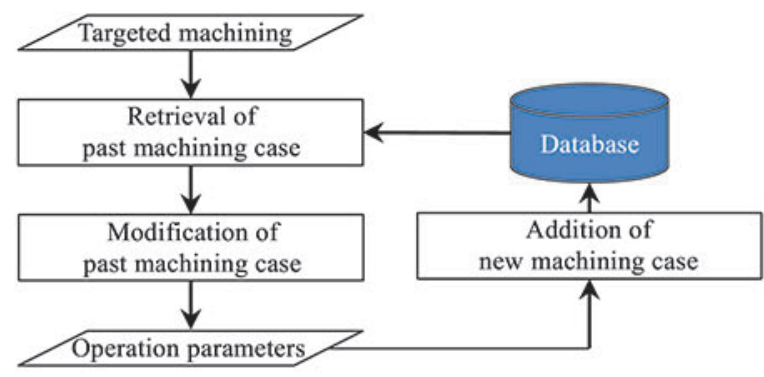

Fig. 2 Flow of developed operation planning system based on case-based reasoning in this study

\begin{tabular}{|c|c|c|}
\hline Type & $\begin{array}{l}\text { Machining feature } \\
\text { Dimension }\end{array}$ & Workpiece material \\
\hline $\begin{array}{l}\text { Through hole } \\
\text { Blind hole } \\
\text { Face P } \\
\text { Closed pocket } \\
\text { : }\end{array}$ & $\begin{array}{l}\text { Length } \\
\text { Width } \\
\text { Height }\end{array}$ & $\begin{array}{l}\text { A5052 } \\
\text { S45C } \\
\text { SUS304 } \\
\text { SPHC } \\
:\end{array}$ \\
\hline
\end{tabular}

\begin{tabular}{|c|c|c|}
\hline Cutting condition & Machining method & Tool entry/exit pattern \\
\hline $\begin{array}{l}\text { Spindle speed } \\
\text { Feed rate } \\
\text { Axial depth of cut } \\
\text { Radial depth of cut }\end{array}$ & $\begin{array}{l}\text { Face milling } \\
\text { Contour milling } \\
\text { Pocket milling } \\
:\end{array}$ & \begin{tabular}{|l|} 
Plunge \\
Rump \\
Helical \\
Side \\
\end{tabular} \\
\hline Tool path pattern & Tool path direction & Tooling \\
\hline $\begin{array}{l}\text { One direction } \\
\text { Concentric in } \\
\text { Trochoid } \\
: \\
\end{array}$ & \begin{tabular}{|l|} 
Longitudinal dir. \\
Short dir. \\
$\mathrm{CW}$ \\
$\mathrm{CCW}$ \\
\end{tabular} & $\begin{array}{l}\text { Tool type } \\
\text { Tool diameter } \\
\text { Blade } \\
\text { Tool material }\end{array}$ \\
\hline \multicolumn{2}{|c|}{ Machining depth } & \\
\hline
\end{tabular}

Fig. 3 Description scheme for machining case in the developed system

そこで本研究では, 事例ベース推論を利用して, CAM ソフト ウェアで NC プログラムを生成するために必要な全ての作業情 報を推定する作業設計支援システムを開発し, 加工準備時間の 短縮を目指す.このため, 割出し 5 軸制御加工も取り扱える先 行研究 ${ }^{13)}$ で認識された加工フィーチャを利用することで, 切削 条件だけでなく加工方法や使用工具なども含めた作業情報を推 定し，工程設計から作業設計を経た NC プログラムの生成まで を自動化することにより, 加工経験の浅い作業者の負担軽減を 図る. また, 加工事例が随時蓄積される実際の加工現場に向け て, データベース内の事例に従って事例検索のルールが自動で 更新される仕組みも導入し, 加工事例に含まれる加工現場独自 のノウハウの継承とその進化を, 推定する作業情報へと反映で きるようにする. 本システムの有用性は, 部品加工を想定したケ ーススタディにより検証する.

\section{2. 作業設計支援システム}

\section{1 システムの概要}

開発した事例ベース推論による作業設計支援システムの流れ を図 2 に示寸. 本システムでは, 認識された加工フィーチャに 対して, 過去の加工事例を蓄積したデータベースから類似の事 例を検索し, 抽出した事例を加工対象に応じて修正して, 推定さ れた作業情報を CAM ソフトウェアへ直接入力できる形式で出 力する. この作業情報は, 加工事例として新たにデータベースへ 追加することも可能である.

本研究で用いる加工事例には, 図 3 のように加工フィーチャ の種類・寸法とワークの材料に加えて CAM ソフトウェアで NC

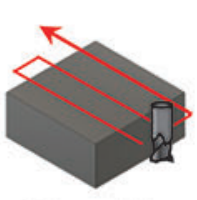

(a) Face milling

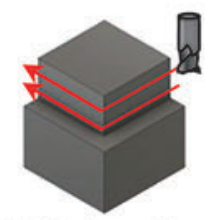

(b) Contour milling

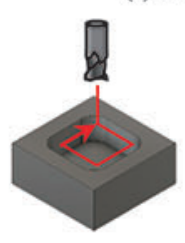

(c) Pocket milling

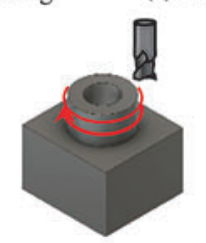

(d) Spiral milling

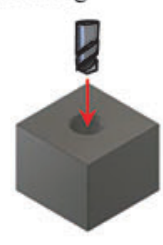

(e) Drilling
Fig. 4 Machining methods considered in this study

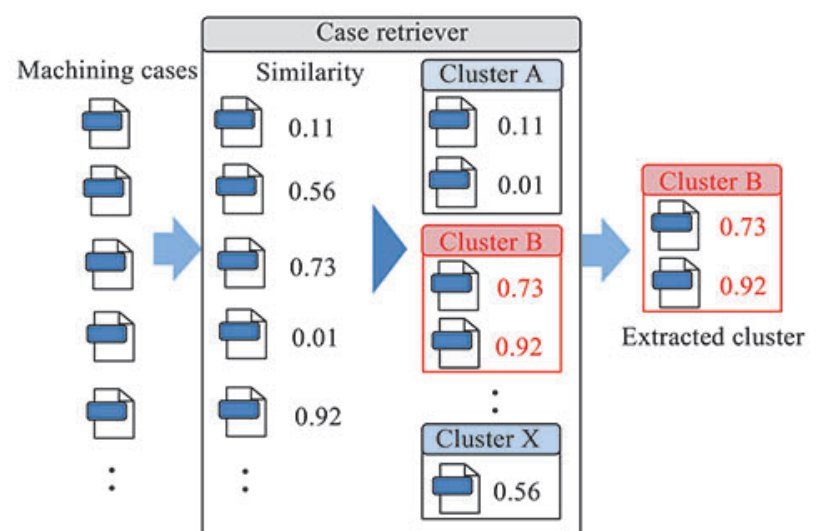

Fig. 5 Cluster extraction for case retrieval by using the $x$-means method

プログラムを生成するために必要な作業情報が含まれており， 加工結果が良好な加工事例のみを取り扱う. 作業情報は, 工具回 転速度, 工具送り速度や切込み量などの切削条件, 加工方法, ツ ーリング, 加工開始面からの深さである加工樑さ, 工具進入・退 出パターン, 工具経路パターンと工具経路方向であり, CAM ン フトウェアの操作履歴としてファイルに保存されている. また, ツーリングは工具の種類, 材料, 直径や刃数, ホルダなどを含ん でおり, 別ファイルにまとめられている. 本研究で対象とする加 エフィーチャは, 4 種類の円柱形状と 8 種類の直方体形状の 12 種類, これらに穴が付加された 12 種類および面取りなどの微小 形状 1 種類の合計 25 種類である ${ }^{5}$. 加工方法は割出し 5 軸制御 加工における図 4 の 5 種類を想定しており, 本研究で対象とし た 25 種類の加工フィーチャはいずれかの方法で加工できる.

なお, 本研究ではCAM ソフトウェアとして, ESPRIT (DPテ クノロジー）を利用し，作業設計支援システムの開発には CAD ソフトウェア Simple Modeler（アイコクアルファ）とその API 機 能, 開発言語としてC\#を用いている.

\section{2 事例検索}

本システムではまず，加工対象と類似した加工事例をデータ ベースから検索する. このとき，図 5 のように過去の加工事例 に対して加工対象との類似度を事例検索器でそれぞれ付与し, 類似度によって加工事例を複数のクラスタに分類して, 類似度 が最大の加工事例を含むクラスタを取り出す. クラスタの作成 に採用している $x$-means 法 ${ }^{14)}$ は, 十分少ない数のクラスタに $k$ means 法で分割した後, 各クラスタに対して適当でないと判断さ れるまで $k$-means 法で 2 分割を繰り返す方法である. 本研究で は, 十分少ないクラスタの数を 2 とし, 元のクラスタおよび $k$ means 法で 2 分割したクラスタ全てでベイズ情報量規準を計算 し，元のクラスタのベイズ情報量規準が小さくなるまで分割を 


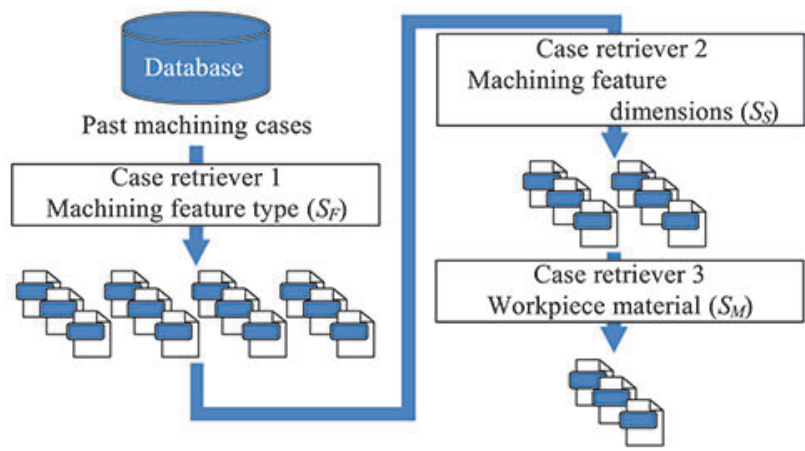

Fig. 6 Flow of case retrieval of past machining cases

Table 1 Example of similarity table regarding machining feature type

\begin{tabular}{c|c|c|c|c}
\hline & Blind hole & Face P & Closed slot & Step \\
\hline Blind hole & 1.00 & 0.10 & 0.23 & 0.21 \\
\hline Face P & 0.10 & 1.00 & 0.21 & 0.40 \\
\hline Closed slot & 0.23 & 0.21 & 1.00 & 0.36 \\
\hline Step & 0.21 & 0.40 & 0.36 & 1.00 \\
\hline
\end{tabular}

繰り返す. また, 図6に示すように, 加工フィーチャの種類, 加 エフィーチャの寸法およびワークの材料に関寸る 3 つの事例検 索器を直列につないで設けているが, 類似度を付与する方法は それぞれ異なる. 加工フィーチャの種類は, 加工方法, 工具の種 類, 工具進入・退出パターンや工具経路パターンなど最も多くの 作業情報に関与するため, 事例検索器 1 で類似する加工事例を 最優先に抽出する. 次に事例検索器 2 では, 工作機械や使用工 具に関係する加工フィーチャの寸法が近い加工事例を抽出する. ワークの材料は, 主に切削条件に関与するが, 切削条件は工作機 械や使用工具も影響するため, 上記で抽出された比較的類似し た加工事例から更に絞り込むために事例検索器 3 で用いる.

加工フィーチャの種類に関する事例検索器 1 では, 表 1 に例 を示したようにテーブルを用いて類似度を導出する. このため にまず，加工フィーチャの種類ごとに加工方法の事例数をパラ メータとして, 以下の特徵ベクトル $v_{i}$ を作成する.

$\boldsymbol{v}_{i}=[$ Machining method A, Machining method $B, \cdots]$

$i$ は加工フィーチャの種類, Machining method A, Machining method $B, \ldots$ は, それぞれ図 4 の 5 種類の加工方法ごとのデータベースに ある事例数である. この特徽べクトル $v_{i}$ を加工フィーチャの種 類ごとに求め, 類似度 $S_{F}$ を式(2)により導出する.

$$
S_{F(j, k)}=\left\{\begin{array}{cl}
0 & \left(\left|v_{j}\right|=0 \text { or }\left|v_{k}\right|=0\right) \\
\left(v_{j} \cdot v_{k}\right) /\left(\left|v_{j}\right|\left|v_{k}\right|\right) & \text { (otherwise) }
\end{array}\right.
$$

ここで $j$ および $k$ は加工フィーチャの種類である. 例えば, 加工 フィーチャの種類 $j$ の特徵ベクトル $v_{j}=[0,8,2,0,0]$ (Machining method $B$ の事例 8 件, Machining method $C$ の事例 2 件, その他 は 0 件)，同様に種類 $k$ の特徵ベクトル $v_{k}=[0,2,16,0,0]$ のとき,

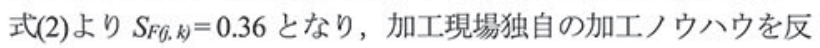
映したデータベースの事例に応じて類似度が変化する。

加工フィーチャの寸法に関する事例検索器 2 では, 加工フィ 一チャ認識時に決定される工具主軸方向と直交する面と工具主 軸方向の高さを加工事例および加工対象で比較して, 類似度 $S S$ を式(3)により導出する.

$$
\begin{aligned}
& S_{s}=\frac{f\left(f\left(l_{c} / l_{t}\right) \cdot f\left(w_{c} / w_{t}\right)\right)}{1+\sqrt{\left(l_{c} / l_{t}-w_{c} / w_{t}\right)^{2}}} \times\left(1-\frac{\left|h_{c}-h_{t}\right|}{h_{c}+h_{t}}\right) \\
& f(a)=\left\{\begin{array}{cc}
(2-a)^{-1} & (0<a<1) \\
a^{-1} & (1 \leq a)
\end{array}\right.
\end{aligned}
$$

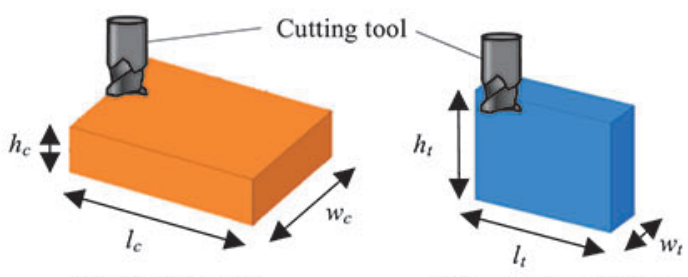

(a) Machining case

(b) Targeted machining

Fig. 7 Definition of machining feature dimensions

Table 2 Example of similarity table regarding workpiece material type

\begin{tabular}{c|c|c|c|c}
\hline & A5052 & S45C & SUS304 & SPHC \\
\hline A5052 & 1.00 & 0.72 & 0.63 & 0.56 \\
\hline S45C & 0.72 & 1.00 & 0.61 & 0.59 \\
\hline SUS304 & 0.63 & 0.61 & 1.00 & 0.91 \\
\hline SPHC & 0.56 & 0.59 & 0.91 & 1.00 \\
\hline
\end{tabular}

このとき, 工具主軸方向の寸法を $h$, 工具主軸方向に直交する寸 法の中で長手方向を $l$, 短手方向を $w$ と図 7 のように定義する. また, 添え字の $c$ および $t$ はそれぞれ加工事例および加工対象の 加工フィーチャ, $a$ は加工事例の加工フィーチャと加工対象の加 エフィーチャの寸法比である. 工具主軸方向と直交する面が加 工事例と加工対象で相似に近ければ式(3)の第一項の分母が小さ な値になり, 完全に相似の場合には最小の 1 となる. また, 寸法 が近いほど式(3)の第一項の分子は大きな值になる. さらに, 第 二項では加工フィーチャの高さが近いほど大きい值となり, 類 似度 $S S$ が大きくなる. なお, 式(4)は寸法比 1 を境に非対称な関 数であり, 加工対象より加工事例の加工フィーチャの寸法が小 さいときに大きな值となる. これにより, 大型工作機械による大 径工具の加工事例よりも, 加工対象と比べて小さい寸法の加工 事例を優先している.

ワークの材料に関する事例検索器 3 では, 表 2 に例を示した ようにテーブルを用いて類似度を導出する. この類似度テーブ ルの作成には, 過去の加工事例における材料ごとの切込み量や 送り速度などの作業情報を含んだ以下の平均特徵ベクトル $\overline{\boldsymbol{x}}_{\alpha}$ を 用いる。

$$
\overline{\boldsymbol{x}}_{\alpha}=\left[\begin{array}{c}
\bar{p}_{1} \\
\bar{p}_{2} \\
\vdots
\end{array}\right]_{\alpha}=\frac{1}{N_{\alpha}} \sum_{n=1}^{N_{\alpha}}\left[\begin{array}{c}
p_{1} \\
p_{2} \\
\vdots
\end{array}\right]_{n}
$$

$\alpha$ は材料の種類であり, $p$ は送り速度や切込み量など材料と関連 する定量的な作業情報で任意に 1 つ以上選択する. $N_{a}$ は材料 $\alpha$ の 加工事例の数を表す. この特徵ベクトル $\overline{\boldsymbol{x}}_{\alpha}$ を材料ごとに求め, 類 似度 $S_{M}$ を式(6)で導出する.

$$
S_{M(\zeta, \eta)}=1-\frac{d_{M}\left(\bar{x}_{\zeta}, \bar{x}_{\eta}\right)}{\max _{\beta, \gamma \in D}\left(d_{M}\left(\bar{x}_{\beta}, \bar{x}_{\gamma}\right)\right)}
$$

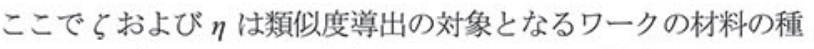
類, $D$ はデータベースに存在する全ての材料の集合であり, $d_{M}$ はマハラノビス距離である. また, $\beta$ および $\gamma$ はマハラノビス距 離が最大となるときの材料の種類である. 例えば, 切削速度と 1 刃あたりの送りを式(5)の $p$ として選択したとき, 材料 A, B , C の平均特徵ベクトルはそれぞれ $\overline{\boldsymbol{x}}_{A}=[142,0.0988], \overline{\boldsymbol{x}}_{B}=[229,0.131]$, $\overline{\boldsymbol{x}}_{C}=[112,0.116]$ のうに表され, マハラノビス距雄は $d_{M}\left(\bar{x}_{A}, \overline{\boldsymbol{x}}_{B}\right)=$ $2.03, d_{M}\left(\bar{x}_{B}, \bar{x}_{C}\right)=1.31, d_{M}\left(\bar{x}_{C}, \bar{x}_{A}\right)=0.85$ と求まり, 式(6)より $S_{M(B,}$ $C_{c}=0.35, S_{M(C, A)}=0.58$ などと計算され, 表 1 と同様にデータベー スの事例に応じて類似度が変化する.

最終的に, 図 6 の 3 つの事例検索器を介して取り出される加 工事例のクラスタには複数の加工事例が含まれており, ここか ら任意の数の加工事例を抽出する. 


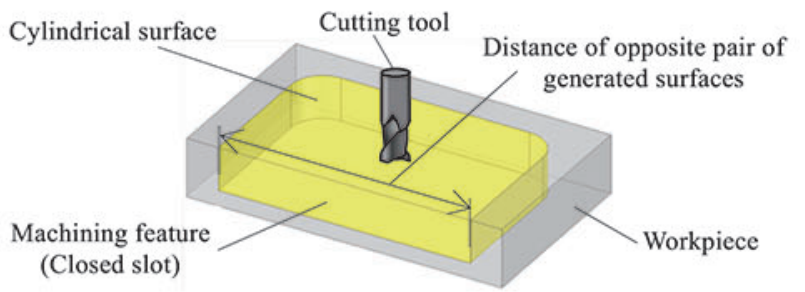

Fig. 8 Distance of opposite pair of generated surfaces and cylindrical generated surfaces in recognized machining feature

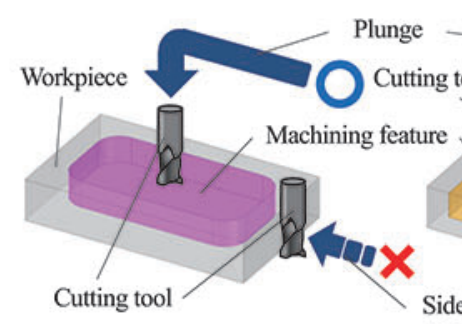

(a) Machining feature of completely closed pocket (b) Machining feature of
opened pocket

Fig. 9 Candidates of considerable tool entry patterns

\section{3 事例修正}

抽出した加工事例を加工対象に応じて修正するため, 作業者 が保有する工具の種類, 直径, 刃数, 有効長, 工具長, ホルダ寸 法やコーティングの有無のツーリング情報を参照する. 加工方 法は, 工具主軸方向と平行な円筒面が創成面となる Through hole などの円柱形状の加エフィーチャの場合には図 4 の(c) (e)から, それ以外の加エフィーチャの場合には(a)〜(c)から抽出された加 工事例の中で最も多い方法を選択する. 工具の種類は, 工具主軸 方向と平行な円筒面が創成面となる円柱形状の加エフィーチャ の場合にはエンドミルやドリルから，それ以外の加エフィーチ ヤの場合にはフェイスミルやエンドミルから選択する. ただし， 加工方法が図 4 の(c)または(d)で, 工具主軸方向と平行な円筒面 が創成面となる円柱形状の加エフィーチャの場合には, エンド ミルを選択し, 加エフィーチャの種類が Chamfer の場合には, 面取り工具も選択の候補に含める. 工具径については, 図 8 に 示す加エフィーチャの創成面間の最短距離未満とし, 円筒面形 状の創成面を含む場合には，さらに円筒面形状の創成面の直径 未満として, この条件を満たす最大径の保有工具を選択する.

工具回転速度, 工具送り速度や切込み量の切削条件は, 切削速

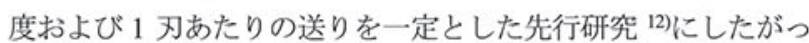
て修正する. なお, 工具の材料, 刃数, コーティングの有無やワ 一クの材料の差異を反映するためには切削条件に修正係数を掛 け合わせる. 加工深さは, 加工フィーチャの工具主軸方向の寸法 に合わせて修正する. 工具進入・退出パターンは, 加エフィーチ ヤの種類や創成面を参照して CAM ソフトウェアのパラメータ を選択する. 利用するCAM ソフトウェアにおいて, フライス加 工の工具進入・退出パターンは工具主軸方向と平行に進入・退出 する Plunge, 斜めに進入・退出する Rump, らせん状に進入する Helical および工具主軸方向と垂直に進入・退出する Side $の ~ 4$ 種 類に大別される. この 4 種類の中から, 抽出された加工事例の 中で最も多いパラメータを選択するが，例えば，図 9 (a)のよう にClosed pocket などの閉じたポケット形状の加エフィーチャの 場合には, 工具主軸方向と垂直な面に工具が進入できない Side は選択しない, 一方, 図 9(b)のように Open pocket などの開いた ポケット形状の加エフィーチャの場合には, 全ての種類が候補 となる.

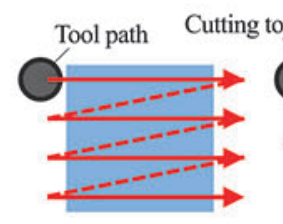

(a) One direction

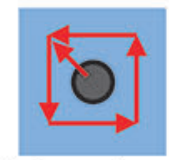

(d) Concentric out

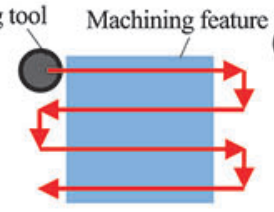

(b) Zig Zag

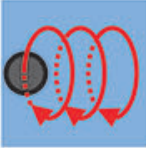

(e) Trochoid

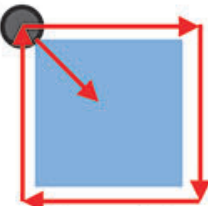

(c) Concentric in

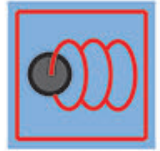

(f) Trochoid + Concentric
Fig. 10 Tool path patterns in used CAM software

工具経路パターンも加工フィーチャの種類や創成面を基に, 抽出された加工事例の中で最も多い CAM ソフトウェアのパラ メータを選択する. 利用する CAM ソフトウェアで用いる工具 経路パターンを図 10 に示寸. ただし, Open pocket などのポケッ 卜形状の加工フィーチャの場合には図 10 の(c)〜(f)から, 工具主 軸方向と平行な円筒面が創成面となる円柱形状の加工フィーチ ヤの場合には図 10 の(d)を選択する. 工具経路方向は抽出された 加工事例の中で最も多い方向を選択する. ただし, 工具経路パタ ーンが図 10 の(a)または(b)で, Open slot のような 2 つの平行な 創成面が 1 組存在する加工フィーチャの場合には, その創成面 と平行な方向を選択し, それ以外の加工フィーチャの場合には, 工具主軸方向に直交する方向のうち, 加エフィーチャの長手方 向と平行な方向を選択する. 以上により, 必要に応じて修正した 作業情報は, 加工フィーチャごとに CAM ソフトウェアへ直接 入力できる形式で出力する.

\section{4 事例登録}

事例登録では, 過去の加工事例や本システムで推定された作 業情報をデータベースへ追加する.このように, 加工現場におい て加工事例は随時蓄積されるが，新たに登録される加工事例を 推定する作業情報へ反映するため, 事例が追加された場合に事 例検索器のルールを自動で更新することが望ましい ${ }^{15}$. また, 加工現場ごとに異なるデータベースに対して，独自のノウハウ を活用できるように事例検索器のルールも加工現場に応じて変 わるのが自然である. そこで本研究では, 加工フィーチャの種類 やワークの材料の類似度テーブルの内容をデータベース内の加 工事例数や加工事例の作業情報と関係付けている. 加工事例が 新たに登録や変更されると, 式(1)および(5)の特徵ベクトルのパ ラメータが変化するため, 類似度テーブルが自動で更新され, 異 なる加工事例が検索されるようになる.

本システムでは，データベースに含まれる加工事例を基に作 業情報を推定しており，データベース内に含まれる加工事例が 多いほど対処できる問題領域が大きくなる. 一方で, 過去の加工 事例がデータベースに残り続ければ最新の工作機械や工具, ワ ークに対して不適切な作業情報を推定する恐れもあり, データ ベースの加工事例を適切に更新して加工現場の変化に対応する ことは今後の課題である.

\section{3. ケーススタディ}

本システムの有用性を検証するため, 機械部品加工メーカよ り提供された加工事例を用いて部品加工を想定したケーススタ ディを実施した．データベース A には 265 件の加工事例が格納 されており, データベース B にはデータベース A の加工事例に 更に 210 件の異なる加工事例を加えて, 加工事例が蓄䅡された 


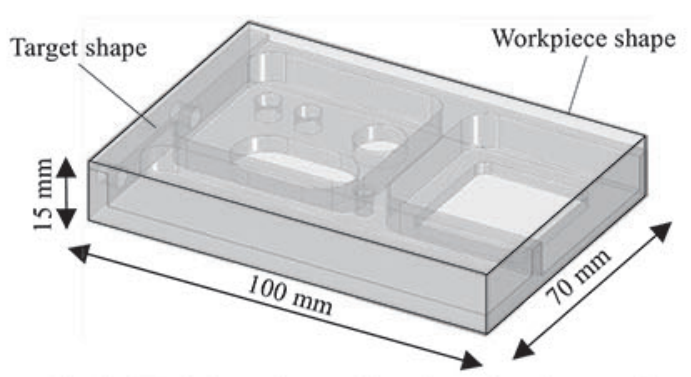

Fig. 11 Workpiece and target shapes in conducted case study

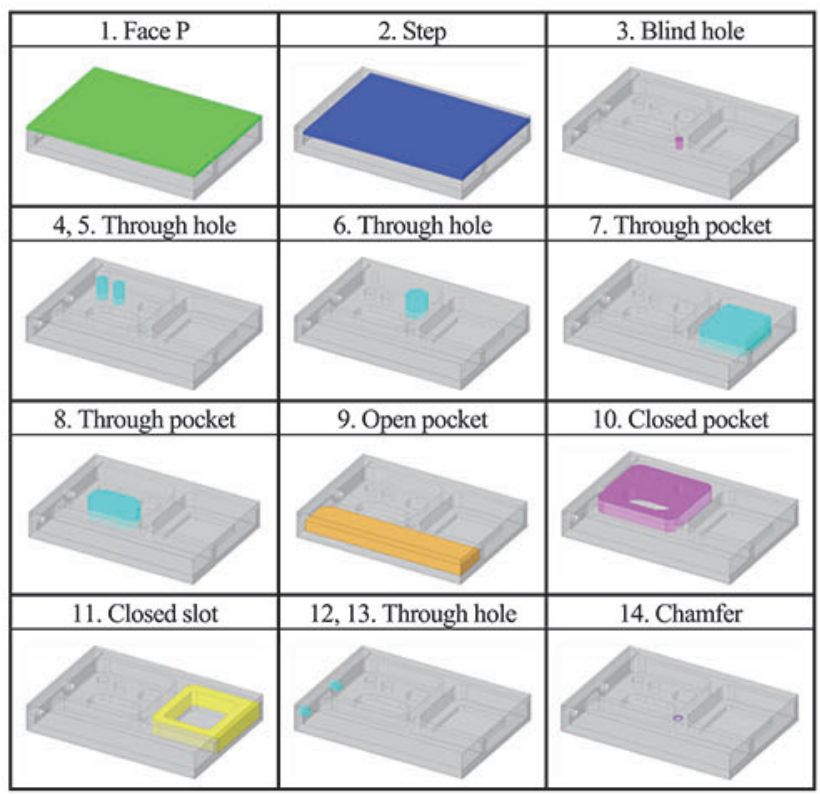

Fig. 12 Recognized machining features and machining sequences

Table 3 Assumed cutting tool in this study

\begin{tabular}{c|c|c|c|c}
\hline Tool type & $\begin{array}{c}\text { Tool } \\
\text { diameter }\end{array}$ & Blade & $\begin{array}{c}\text { Tool } \\
\text { material }\end{array}$ & Coating \\
\hline Face mill & 50 & 4 & WC & Coated \\
\hline Flat endmill & 25 & 2 & HSS & Uncoated \\
\hline Flat endmill & 14 & 2 & HSS & Uncoated \\
\hline Flat endmill & 10 & 2 & HSS & Uncoated \\
\hline Flat endmill & 8 & 2 & HSS & Uncoated \\
\hline Flat endmill & 4 & 2 & HSS & Uncoated \\
\hline Drill & 12 & 2 & HSS & Coated \\
\hline Drill & 6.1 & 2 & HSS & Coated \\
\hline Drill & 4 & 2 & HSS & Coated \\
\hline Chamfer & - & 4 & WC & Coated \\
\hline
\end{tabular}

Table 4 Similarity table regarding machining feature type (DB A $\rightarrow$ B)

\begin{tabular}{c|c|c|c|c}
\hline & Blind hole & Face $P$ & Closed slot & Step \\
\hline Blind hole & 1.00 & $0.10 \rightarrow 0.03$ & $0.23 \rightarrow 0.11$ & $0.21 \rightarrow 0.12$ \\
\hline Face $P$ & $0.10 \rightarrow 0.03$ & 1.00 & $0.21 \rightarrow 0.19$ & $0.40 \rightarrow 0.36$ \\
\hline Closed slot & $0.23 \rightarrow 0.11$ & $0.21 \rightarrow 0.19$ & 1.00 & $0.36 \rightarrow 0.84$ \\
\hline Step & $0.21 \rightarrow 0.12$ & $0.40 \rightarrow 0.36$ & $0.36 \rightarrow 0.84$ & 1.00 \\
\hline
\end{tabular}

Table 5 Similarity table regarding workpiece material type $(\mathrm{DB} A \rightarrow \mathrm{B})$

\begin{tabular}{c|c|c|c|c}
\hline & A5052 & S45C & SUS304 & SPHC \\
\hline A5052 & 1.00 & $0.72 \rightarrow 0.57$ & $0.63 \rightarrow 0.88$ & $0.56 \rightarrow 0.91$ \\
\hline S45C & $0.72 \rightarrow 0.57$ & 1.00 & $0.61 \rightarrow 0.65$ & $0.59 \rightarrow 0.88$ \\
\hline SUS304 & $0.63 \rightarrow 0.88$ & $0.61 \rightarrow 0.65$ & 1.00 & $0.91 \rightarrow 0.57$ \\
\hline SPHC & $0.56 \rightarrow 0.91$ & $0.59 \rightarrow 0.88$ & $0.91 \rightarrow 0.57$ & 1.00 \\
\hline
\end{tabular}

状態を再現している. この 2 つのデータベースを用いて, それ ぞれ作業設計を施し，その推定結果を比較する. 図 11 に本ケー ススタディで用いたワーク形状および目標形状, 図 12 に認識さ れた加工フィーチャおよび加工順序を示す. ワークの材料は A5052 とし, 表 3 にまとめた保有工具を想定した. また，ワー

Case retriever 1 : Machining feature type
\begin{tabular}{|c|c|c|c|c|c|}
\hline \multicolumn{5}{|c|}{ Databe B } \\
\hline \multicolumn{7}{|c|}{$C_{F I}$} \\
\hline Data no. & $S_{F}$ & Feature type & Data no. & $S_{F}$ & Feature type \\
\hline 85 & 0.99 & Open slot & 51 & 0.24 & Blind hole \\
\hline 150 & 0.96 & Step & 56 & 0.15 & Through hole \\
\hline 313 & 1.00 & Through pocket & 310 & 0.34 & Chamfer \\
\hline 434 & 0.90 & Closed pocket & 380 & 0.31 & Face P \\
\hline \multicolumn{2}{|c|}{$:$} & 108 cases & $:$ & 367 cases \\
\hline
\end{tabular}

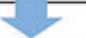

\begin{tabular}{|c|c|c|c|c|c|}
\hline \multicolumn{6}{|c|}{ Case retriever 2 : Machining feature dimensions } \\
\hline \multicolumn{3}{|c|}{$C_{S I}$} & \multicolumn{3}{|c|}{$C_{S 2}$} \\
\hline Data no. & $S_{S}$ & $\left(l_{c}, w_{c}, h_{c}\right)$ & Data no. & $S_{S}$ & $\left(l_{c}, w_{c}, h_{c}\right)$ \\
\hline 85 & 0.43 & $(100,80,20)$ & 66 & 0.20 & $(150.0,90,50)$ \\
\hline 130 & 0.36 & $(16,12,9)$ & 69 & 0.01 & $(10,2,135)$ \\
\hline 313 & 0.54 & $(66,65,9)$ & 194 & 0.14 & $(539,10,10)$ \\
\hline 420 & 0.58 & $(49,44,15.5)$ & 434 & 0.27 & $(274.6,120.8,4.0)$ \\
\hline \multicolumn{2}{|l|}{$:$} & 43 cases & \multicolumn{2}{|l|}{$:$} & 65 cases \\
\hline \multicolumn{6}{|c|}{ etriever 3: Workpiece material } \\
\hline \multicolumn{3}{|c|}{$C_{M I}$} & \multicolumn{3}{|c|}{$C_{M 2}$} \\
\hline Data no. & $S_{M}$ & Material type & Data no. & $S_{M}$ & Material type \\
\hline 313 & 1.00 & A5052 & 85 & 0.70 & $\mathrm{FC}$ \\
\hline 365 & 0.91 & SPHC & 150 & 0.70 & $\mathrm{FC}$ \\
\hline 420 & 0.88 & SUS304 & 212 & 0.70 & $\mathrm{FC}$ \\
\hline \multicolumn{2}{|l|}{$:$} & 22 cases & \multicolumn{2}{|l|}{$:$} & 16 cases \\
\hline \multicolumn{3}{|c|}{5} & \multicolumn{3}{|c|}{$C_{M 3}$} \\
\hline \multicolumn{3}{|c|}{$C_{M I}$} & Data no. & $S_{M}$ & Material type \\
\hline \begin{tabular}{|l|} 
Data no. \\
\end{tabular} & $S_{T}$ & $\left(S_{F}, S_{S}, S_{M}\right)$ & 20 & 0.42 & S45C-H \\
\hline 313 & 10046 & $(1.00,0.54,1.00)$ & 130 & 0.42 & S45C-H \\
\hline 73 & 10032 & $(1.00,0.32,0.88)$ & 143 & 0.57 & S45C \\
\hline 345 & 9073 & $(0.90,0.33,1.00)$ & \multicolumn{2}{|l|}{$:$} & 5 cases \\
\hline \multicolumn{2}{|l|}{ : } & 22 cases & & & \\
\hline
\end{tabular}

Fig. 13 Flow of extraction of past machining case in machining operation 7

Table 6 Parameters of extracted machining case and its modification at machining operation 7

\begin{tabular}{c|c|c}
\hline & Case parameters & Inferred parameters \\
\hline Machining method & Pocket machining & Pocket machining \\
\hline Cutting tool & Flat end mill $\phi 16$ & Flat end mill $\phi 4$ \\
\hline Spindle speed $\mathrm{min}^{-1}$ & 750 & 3000 \\
\hline Feed rate $\mathrm{mm} / \mathrm{min}^{-}$ & 220 & 704 \\
\hline Radial depth of cut $\mathrm{mm}$ & 1.0 & 0.25 \\
\hline Axial depth of cut $\mathrm{mm}$ & 9.0 & 1.8 \\
\hline Machining depth $\mathrm{mm}$ & 9.0 & 11.4 \\
\hline Tool entry pattern & Plunge & Plunge \\
\hline Tool exit pattern & Side & Plunge \\
\hline Tool path pattern & Concentric out & Concentric out \\
\hline Tool path direction & CCW & CCW
\end{tabular}

クの材料の類似度テーブルを導出する際に使用する作業情報は 切削速度と 1 刃当たりの送りとし, 抽出する加工事例は, 3 つの 事例検索器で取り出されたクラスタの中から, 式(7)により加工 作業の類似度 $S_{T}$ が最大の加工事例を選択した。

$$
S_{T}=W_{F} \times S_{F}+W_{S} \times S_{S}+W_{M} \times S_{M}
$$

ここでは $3 つ の$ 類似度の重み $\left(W_{F}, W_{S}, W_{M}\right)$ として $\left(10^{4}, 10^{2}, 1\right)$ を用 いたが,これは加工フィーチャの種類の類似度を優先するよう に経験的に決定しており，作業者が重視する加工精度や加工時 問などに応じて適切な重みを決定することは今後の課題である. 加工フィーチャの種類およびワークの材料の類似度テーブルに 
Table 7 Machining case parameters extracted from different database

\begin{tabular}{|c|c|c|c|c|}
\hline \multirow[t]{2}{*}{ Seq. } & $\begin{array}{l}\text { Past machining } \\
\text { case number }\end{array}$ & \multicolumn{3}{|c|}{$\begin{array}{c}\text { Machining method / Cutting tool } \\
\text { Spindle speed } \mathrm{min}^{-1} / \text { Feed rate } \mathrm{mm} / \mathrm{min} \text {. } \\
\text { Radial depth of cut } \mathrm{mm} / \text { Axial depth of cut } \mathrm{mm} \\
\text { Tool entry pattern / Tool exit pattern }\end{array}$} \\
\hline & & Database A & & Database B \\
\hline 1 & 192 & $\begin{array}{c}\text { Face milling / Face mill } \phi 80 \\
1090 / 1308 \\
62 / 0.5 \\
\text { Side / Side }\end{array}$ & 380 & $\begin{array}{c}\text { Pocket milling / Face mill } \phi 20 \\
2380 / 714 \\
15 / 1.0 \\
\text { Plunge / Rump }\end{array}$ \\
\hline 2 & 193 & $\begin{array}{r}\text { Pocket milli } \\
10 \\
\text { Sid }\end{array}$ & $\begin{array}{l}\mathrm{ng} / \mathrm{F} \\
90 / 1 \\
60 / 0 . \\
\mathrm{e} / \mathrm{Pl}\end{array}$ & $\begin{array}{l}\text { ace mill } \phi 80 \\
308 \\
5 \\
\text { ange }\end{array}$ \\
\hline 3 & 51 & $\begin{array}{r}\text { Drillin } \\
36\end{array}$ & $\begin{array}{l}\mathrm{g} / \mathrm{Dr} \\
538 / 2 \\
-/- \\
-/-\end{array}$ & $\begin{array}{l}\text { ill } \phi 2.8 \\
218\end{array}$ \\
\hline $\begin{array}{l}4 \\
5\end{array}$ & 261 & $\begin{array}{c}\text { Drilling / Drill } \phi 9 \\
2470 / 371 \\
-/- \\
-/- \\
\end{array}$ & 358 & $\begin{array}{c}\text { Spiral milling / End mill } \phi 6 \\
790 / 158 \\
-/- \\
\text { Helical / Plunge }\end{array}$ \\
\hline 6 & 245 & $\begin{array}{c}\text { Drilling / Drill } \phi 11 \\
570 / 104 \\
-/- \\
-/-\end{array}$ & 362 & $\begin{array}{c}\text { Drilling / Drill } \phi 11 \\
570 / 104 \\
-/- \\
-/-\end{array}$ \\
\hline 7 & 73 & $\begin{array}{c}\text { Contour milling / End mill } \phi 12 \\
1326 / 477 \\
8.4 / 12.0 \\
\text { Side / Side } \\
\end{array}$ & 313 & $\begin{array}{c}\text { Pocket milling / End mill } \phi 16 \\
750 / 220 \\
0.69 / 9.0 \\
\text { Plunge / Side } \\
\end{array}$ \\
\hline 8 & 73 & $\begin{array}{c}\text { Contour milling / End mill } \phi 12 \\
1326 / 477 \\
8.4 / 12.0 \\
\text { Side / Side } \\
\end{array}$ & 296 & $\begin{array}{c}\text { Pocket milling / End mill } \phi 16 \\
1590 / 1110 \\
1.0 / 10.0 \\
\text { Plunge / Side } \\
\end{array}$ \\
\hline 9 & 171 & $\begin{array}{c}\text { Contour milling / End mill } \phi 20 \\
1980 / 594 \\
0.5 / 0.5 \\
\text { Side / Side } \\
\end{array}$ & 400 & \begin{tabular}{|c|} 
Pocket milling/ End mill $\phi 12$ \\
$1720 / 261$ \\
$9.0 / 1.0$ \\
Plunge / Plunge \\
\end{tabular} \\
\hline 10 & 146 & $\begin{array}{r}\text { Pocket mill } \\
50 \\
\text { Rum }\end{array}$ & $\begin{array}{l}\text { ling } / 1 \\
10 / 1 \\
0.8 / 5 \\
\mathrm{np} / \mathrm{Pl}\end{array}$ & $\begin{array}{l}\text { End mill } \phi 8 \\
503 \\
.0 \\
\text { lunge }\end{array}$ \\
\hline 11 & 76 & $\begin{array}{r}\text { Contour mil } \\
15 \\
1 \\
\text { Sid } \\
\end{array}$ & $\begin{array}{l}\text { ling / } \\
592 / 5 \\
1.2 / 1 \\
\text { le / R }\end{array}$ & $\begin{array}{l}\text { End mill } \phi 16 \\
573 \\
1.5 \\
\text { Imp }\end{array}$ \\
\hline $\begin{array}{l}12 \\
13\end{array}$ & 56 & $\begin{array}{r}\text { Spiral milli } \\
21 \\
\text { Plun } \\
\end{array}$ & $\begin{array}{l}\text { ng/E } \\
149 / 4 \\
-/- \\
\mathrm{ge} / \mathrm{P}\end{array}$ & $\begin{array}{l}\text { ind mill } \phi 16 \\
173 \\
\text { lunge }\end{array}$ \\
\hline 14 & 260 & $\begin{array}{c}\text { Drilling / Chamfer } \\
350 / 35 \\
-/- \\
-/-\end{array}$ & 310 & $\begin{array}{c}\text { Drilling / Chamfer } \\
500 / 50 \\
-/- \\
-/-\end{array}$ \\
\hline
\end{tabular}

ついて, データベース A と B それぞれで導出されたテーブルの 一部を表 4 および表 5 に示す. 表内では左にデータベース A, 右にデータベース B での類似度を記载しているが，加工事例が 蓄積されることで類似度が変化していることが分かる.

図 12 の加工作業 7 を例として, データベース B の加工事例に 対する事例検索の流れを図 13 に示寸.ここでは, まず表 4 の加 エフィーチャの種類の類似度テーブルにより, 類似度 $S_{F}$ が加工 事例に付与され，この $S_{F}$ を基にクラスタ $C_{F 1}$ または $C_{F 2}$ へ加工 事例が分類されている. 次に, 最大の $S_{F}$ を含むクラスタ $C_{F I}$ の 加工事例が加工フィーチャの寸法に関する事例検索器へ入力さ れ，類似度 $S_{s}$ が付与されて，この $S_{s}$ を基にクラスタ $C_{S I}$ または $C_{S 2}$ へ加工事例が分類されている. 同様に, 最大の $S_{s}$ を含むクラ スタ $C_{S l}$ の加工事例が次のワークの材料に関する事例検索器へ 入力され, 表 5 のワークの材料の類似度テーブルにより, 類似 度 $S_{M}$ が加工事例に付与され, クラスタ $C_{M I}, C_{M 2}$ または $C_{M 3}$ へ加
Table 8 Operation parameters inferred according to different database

\begin{tabular}{|c|c|c|}
\hline \multirow[t]{2}{*}{ Seq. } & \multicolumn{2}{|c|}{$\begin{array}{c}\text { Machining method / Cutting tool } \\
\text { Spindle speed } \mathrm{min}^{-1} / \text { Feed rate } \mathrm{mm} / \mathrm{min} \text {. } \\
\text { Radial depth of cut } \mathrm{mm} \text { / Axial depth of cut } \mathrm{mm} \\
\text { Tool entry pattern / Tool exit pattern }\end{array}$} \\
\hline & Database A & Database B \\
\hline 1 & $\begin{array}{c}\text { Face milling / Face mill } \phi 50 \\
2442 \text { / } 2686 \\
38.8 / 0.5 \\
\text { Side / Side }\end{array}$ & $\begin{array}{c}\text { Pocket milling / Face mill } \phi 50 \\
1333 \text { / } 550 \\
37.5 \text { / } 1.0 \\
\text { Plunge / Rump }\end{array}$ \\
\hline 2 & \multicolumn{2}{|c|}{$\begin{array}{c}\text { Pocket milling / End mill } \phi 25 \\
4883 / 4297 \\
18.75 / 0.47 \\
\text { Side / Plunge }\end{array}$} \\
\hline 3 & \multicolumn{2}{|c|}{$\begin{array}{c}\text { Drilling / Drill } \phi 4 \\
2547 / 153 \\
-/- \\
-/-\end{array}$} \\
\hline $\begin{array}{l}4 \\
5\end{array}$ & $\begin{array}{l}\text { Drilling / Drill } \phi 6.1 \\
8503 \text { / } 2004 \\
-/- \\
-/-\end{array}$ & $\begin{array}{c}\text { Spiral milling / End mill } \phi 4 \\
1989 \text { / } 62 \\
-/ \text { - } \\
\text { Helical / Plunge }\end{array}$ \\
\hline 6 & $\begin{array}{l}\text { Drilling / Drill } \phi 12 \\
732 \text { / } 146 \\
-/- \\
-/-\end{array}$ & $\begin{array}{c}\text { Drilling / Drill } \phi 12 \\
732 / 146 \\
-/- \\
-/-\end{array}$ \\
\hline 7 & $\begin{array}{c}\text { Contour milling / End mill } \phi 4 \\
9282 \text { / } 5251 \\
2.8 \text { / } 4.0 \\
\text { Plunge / Plunge }\end{array}$ & $\begin{array}{c}\text { Pocket milling / End mill } \phi 4 \\
3000 / 704 \\
0.25 / 1.8 \\
\text { Plunge / Plunge }\end{array}$ \\
\hline 8 & $\begin{array}{c}\text { Contour milling / End mill } \phi 14 \\
2652 \text { / } 1500 \\
9.8 / 11.4 \\
\text { Plunge / Plunge }\end{array}$ & $\begin{array}{c}\text { Pocket milling / End mill } \phi 14 \\
1817 / 1015 \\
0.88 / 7.0 \\
\text { Plunge / Plunge } \\
\end{array}$ \\
\hline 9 & $\begin{array}{c}\text { Contour milling / End mill } \phi 10 \\
5544 \text { / } 1830 \\
0.25 / 0.25 \\
\text { Side / Side }\end{array}$ & $\begin{array}{c}\text { Pocket milling / End mill } \phi 10 \\
2890 / 483 \\
7.5 / 0.83 \\
\text { Plunge / Plunge }\end{array}$ \\
\hline 10 & \multicolumn{2}{|c|}{$\begin{array}{c}\text { Pocket milling / End mill } \phi 8 \\
7014 \text { / } 1852 \\
0.8 \text { / } 4.0 \\
\text { Rump / Plunge }\end{array}$} \\
\hline 11 & \multicolumn{2}{|c|}{$\begin{array}{c}\text { Contour milling / End mill } \phi 10 \\
5941 / 3361 \\
7.0 / 1.9 \\
\text { Side / Rump } \\
\end{array}$} \\
\hline $\begin{array}{l}12 \\
13\end{array}$ & \multicolumn{2}{|c|}{$\begin{array}{c}\text { Spiral milling / End mill } \phi 4 \\
2057 \text { / } 149 \\
-/ \text { - } \\
\text { Plunge / Plunge }\end{array}$} \\
\hline 14 & $\begin{array}{c}\text { Drilling / Chamfer } \\
\begin{array}{c}204 / 40 \\
-/- \\
-/-\end{array}\end{array}$ & $\begin{array}{c}\text { Drilling / Chamfer } \\
\begin{array}{c}625 / 78.1 \\
-/- \\
-/-\end{array}\end{array}$ \\
\hline
\end{tabular}

工事例が分類されて, 最終的に, 最大の $S_{M}$ を含むクラスタであ る $C_{M I}$ から類似度 $S_{T}$ が最大の加工事例が抽出されている.

次に, 抽出された加工事例は, 加工対象に応じて表 6 のよう に修正される.ここでは, 加エフィーチャの種類が Through pocket であるため, 表 3 のフェイスミルやフラットエンドミル が工具の種類の候補となる. 工具径は創成面間の最短距離が 28 $\mathrm{mm}$ であるものの, R $2.5 \mathrm{~mm}$ の円筒状の創成面を有するため, 工具径は $5 \mathrm{~mm}$ 末満となる. したがって, ここでは $\phi 4 \mathrm{~mm} の>$ ラットエンドミルが選択されている. 切削条件は先行研究 12)を 基に修正される. 例えば, 加工事例の工具回転速度と送り速度は それぞれ $750 \mathrm{~min}^{-1}, 220 \mathrm{~mm} / \mathrm{min}$ であり，切削速度を一定とする と工具回転速度が $3000 \mathrm{~min}^{-1}$ となり, 工具刃数の差異を反映させ る修正係数が 0.8 であるため, 送り速度は 0.8 × 220 × $3000 / 750$ $=704 \mathrm{~mm} / \mathrm{min}$ と修正されている. 加工梁さは加工フィーチャの 工具主軸方向の寸法に合わせて $11.4 \mathrm{~mm}$ に修正されている. 工 


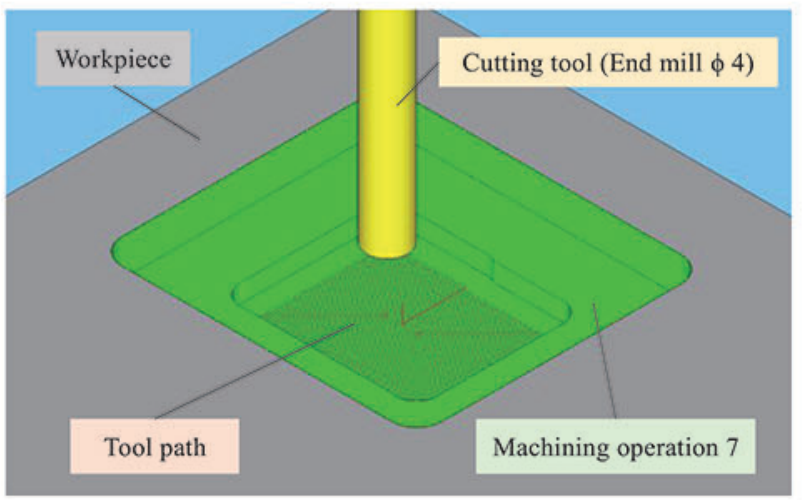

Fig. 14 Machining simulation of machining operation 7 in CAM software

具進入・退出パターンは加工フィーチャの種類が Trough pocket であるため, 工具主軸方向と平行な方向に進入・退出する Plunge が選択され, 工具経路パターンおよび工具経路方向は加工事例 の作業情報を基に, それぞれ Concentric out および CCW が選択 されている.

データベース $\mathrm{A}$ および $\mathrm{B}$ それぞれで抽出された加工事例と推 定された作業情報の一部を表 7, 表 8 に示寸. データベース B に 追加された加工事例の影響で, 図 12 の加工作業 1, 4 9 および 14 では, 2 つのデータベースにおいて異なる加工事例が抽出さ れていることが分かる. 加工作業 $1,4,5$ および7〜9では, 抽 出された加工事例の加工方法の違いから, 加工作業 7 の Contour milling と Pocket milling のように異なる加工方法が選択されてい る. また, 抽出された加工事例における使用工具や切削条件の違 いから, 加工作業 1，4，5，7９および 14 では, 異なる切削条 件が推定されている. さらに, 加工作業 7 および 8 では, 加工 フィーチャの種類が Through pocket であることから, 工具進入・ 退出パターンが Side から, Plunge 一と修正されている.ここで 推定された作業情報を用いて, 図 14 のようにCAM ソフトウェ アを用いて切削シミュレーションを実施した結果, 目標形状に 至るまで問題なく加工できることを確認した.

以上から, データベースに蓄積された加工事例に応じて, 加工 事例が抽出され, 推定する作業情報も変化するとともに, NCプ ログラムを生成するのに必要な作業情報が本システムにより適 切に推定できることが分かった.

\section{4. 結 論}

本研究では, 部品加工の準備時間を短縮するために, 加工フィ 一チャを利用した事例ベース推論によって, CAM ソフトウェア で NC プログラムを生成するために必要な作業情報を推定でき る作業設計支援システムを開発した. また, 異なる加工事例が登 録されたデータベースを用いて, 認識された加工フィーチャご との作業情報を推定するケーススタディにより, 本システムの 有用性を検証し, 以下の結論を得た.
(1) 加工フィーチャの種類・寸法とワークの材料を用いて, 加工対象と類似した加工事例を抽出し, 加工事例の作業 情報を加工対象に合わせて修正する事例ベース推論に より切削条件だけでなく, 加工方法や使用工具なども含 めた NCプログラムの生成に必要な作業情報を推定でき ることを示した.

（2）蓄積された加工事例が異なる 2 つのデータベースを準 備してそれぞれで作業設計を施した結果, データベース ごとに事例検索器のルールが自動で変更されることで, 抽出される加工事例が変化するとともに, 推定される作 業情報にも差異が生じ, 蓄樻された加工事例に含まれる 加工現場独自のノウハウが継承できる可能性を示した.

\section{参 考 文 献}

1) W. Fu, A. A. Eftekharian and M. I. Campbell: Automated Manufacturing Planning Approach Based on Volume Decomposition and Graph-Grammars, Journal of Computing and Information Science in Engineering, 13, 2 (2013) 021010.

2) K. Dwijayanti and H. Aoyama: Basic Study on Process Planning for TurningMilling Center Based on Machining Feature Recognition, Journal of Advanced Mechanical Design, Systems and Manufacturing, 8, 4 (2014) JAMDSM0058.

3) E. Morinaga, T. Hara, H. Joko, H. Wakamatsu and E. Arai: Improvement of Computational Efficiency in Flexible Computer-Aided Process Planning, International Journal of Automation Technology, 8, 3(2014) 396.

4) Y. Shi, Y. Zhang, K. Xia and R. Harik: A Critical Review of Feature Recognition Techniques, Computer-Aided Design and Applications, 17, 5 (2020) 861 .

5) 井上友貴, 中本圭一:複雑部品の切削加工に向けた工程設計支援シス テムのための加工フィーチャ認識手法の提案, 日本機械学会論文集, 83, 850 (2017) 16-00574.

6) Y. Inoue and K. Nakamoto: Development of a CAPP System for MultiTasking Machine Tools to Deal with Complicated Machining Operations, Journal of Advanced Mechanical Design, Systems, and Manufacturing, 14, 1 (2020) JAMDSM0006.

7) A. Iqbal, N. He, L. Li, N. Dar: A Fuzzy Expert System for Optimizing Parameters and Predicting Performance Measures in Hard-Milling Process, Expert Systems with Applications, 32, 4 (2007) 1020.

8) 佐藤雄磨, 森重功一:XMLにより記述された加工情報データベース を利用した作業設計支援システムの開発, 精密工学会誌, 74, 1 (2008) 92.

9) 児玉紘幸, 廣垣俊樹, 青山栄一, 小川圭二: 工具カタログデータにデ ータマイニング手法を応用した粗加工用切削条件決定支援, 砥粒加 工学会誌, 56, 12 (2012) 824.

10) 椎木祐策, M. M. Isnaini, 佐藤隆太, 白瀬敬一 : 加工事例を再利用して NCプログラムを作成する機械加工用作業設計システム, 日本機械学 会論文集, 81, 832 (2015) 15-00280.

11) I. Nishida, and K. Shirase: Automatic Determination of Cutting Conditions for NC Program Generation by Reusing Machining Case Data Based on Geometric Properties of Removal Volume, Journal of Advanced Mechanical Design, Systems, and Manufacturing, 12, 4 (2018) JAMDSM 0093.

12）長野竜也，白瀬敬一，若松栄史，荒井栄司 : 事例ベース推踚に基づく 切削条件推論システム, 精密工学会誌, 67,9(2001) 1485.

13) Y. Watanabe and K. Nakamoto: Proposal of a Machining Features Recognition Method for 5-Axis Index Milling on Multi-Tasking Machine Tools, Journal of Advanced Mechanical Design, Systems, and Manufacturing, 14, 7 (2020) JAMDSM0108.

14) 石岡恒憲: $x$-means 法改良の一提案 $-k$-means 法の逐次絽り返しとク ラスターの再併合一, 計算機統計学, 18,1 (2006) 3.

15) 秋藤俊介, 辻洋:バージョン空間法を応用した類似事例の検索と索引 の更新方式, 情報処理学会埨文誌, 36, 1 (1995) 41. 